\title{
Resenha: Filhos: opção ou dever?
}

\author{
Rosani Gambatto \\ André Luiz Picolli da Silva \\ Universidade do Oeste de Santa Catarina
}

\section{Book Review: Children: an Option or a Duty?}

Poder ter filhos, significa necessariamente desejar, conseguir ou dever tê-los? Questões como estas surgem no cotidiano de mulheres que, por opção ou circunstância não possuem filhos. $\mathrm{O}$ tema da não-maternidade mobiliza emocionalmente várias mulheres, pois, não ter filhos implica em não realizar um potencial, em desviar-se de um padrão construído socialmente, sendo que, a feminilidade para a maioria da sociedade, está associada à maternidade. No entanto, escapando à concepção linear de feminilidade/ maternidade, a vida das mulheres contemporâneas pode ter dimensões variadas e satisfatórias, como: carreira profissional, trabalho, estudo, diversão. É com essa noção de mulher e mais especificamente da maternidade e nãomaternidade que Luci H. B. Mansur, em seu livro "Sem filhos: a mulher singular no plural" explora o fenômeno da não-maternidade, buscando ultrapassar abordagens tradicionais e, por vezes preconceituosas.

A autora apresenta um estudo qualitativo e exploratório das dimensões atribuídas à não-maternidade e as contribuições do saber científico de diversas áreas das ciências humanas e sociais. O livro trata, portanto, de um fenômeno dificilmente redutível a um único determinante, sendo que, sua compreensão requer a revisão das expectativas da sociedade, em relação aos papéis femininos tradicionais, bem como o questionamento do instinto materno, do reconhecimento e a aceitação da diversidade dos desejos e das circunstâncias das mulheres ocidentais contemporâneas. A escrita do livro, assim, é moldada na intersecção entre história, cultura, sociedade, família e personalidade, desmistificando a idéia da não-maternidade ligada à inferioridade ou patologia.

De acordo com a autora, principalmente no século XXI, é possível perceber que a sexualidade das mulheres não se encontra mais refletida somente na maternidade. As fronteiras entre o espaço da família e o espaço do trabalho vêm sendo redefinidas, o que provoca a falência do modelo referencial de conjugalidade convencional, visto que, a mulher possui outras opções para integrar-se à sociedade. Tendo em vista as transformações dos desejos e necessidades humanas, é possível identificar que lugares sociais pré-definidos e caminhos naturalizados, deixaram

1 Endereço: Rua José Veronese, 299, Bairro Santa Rita, São Miguel do Oeste, SC, Brasil 89900-000.E-mail: rosani_gambatto@yahoo.com.br de ordenar o destino feminino que se tornou, muitas vezes, imprevisível. Nesse sentido, as mulheres, estão diante da possibilidade de se auto-inventarem cada vez mais e, no jogo de espelhos socioculturais, produzisr imagens inéditas, nas quais, inexistem modelos pré-determinados de certo e errado, existindo isso sim, leituras ambíguas e divergentes dessas imagens.

Da segunda metade do século XX em diante - com a inserção definitiva da mulher no mercado de trabalho; o acesso à formação profissional e às atividades antes exclusivamente masculinas, o domínio sobre a procriação e o prazer resultante do advento da pílula anti-concepcional, as alterações da organização familiar e do vínculo conjugal - foram rompidos antigos padrões e revistas inúmeras convicções (estudo, profissão, carreira, casamento, filhos). Ao ser desvitalizado o ideal da mulher no lar, a relação entre os sexos começa a ser redefinida e as mulheres percebem que essa imagem fixa da maternidade-fecundidade, moldada pela biologia, não necessariamente lhes convém, pois a estrita circunscrição no papel materno promove a exclusão de outros espaços, considerados por elas mais importantes no atual momento de suas vidas. Com isso, permanecer sem filhos significa viver uma diferença significativa em relação à comunidade e, sobretudo, a comunidade das mulheres-mães.

No livro, Mansur apresenta a perspectiva de oito mulheres, residentes na região central, e pertencentes aos segmentos sociais médios da cidade de São Paulo. Todas com formação universitária, economicamente independentes, das diversas áreas de trabalho, com faixa etária entre 40 e 50 anos, e que, por sua vez, optaram por permanecer sem filhos, uma vez que a maternidade para elas representava uma limitação da liberdade e dos objetivos pessoais e profissionais. As mulheres que buscaram uma inserção social vinculada à não-maternidade (cujo exercício implicaria em encargos e compromissos considerados por elas limitadores de seus objetivos prioritários) se diferenciaram da "sentença biológica", e demonstraram ter uma percepção de si mesmas como pessoas produtivas e realizadas - independente de suas escolhas reprodutivas. Em cada experiência das mulheres entrevistadas é possível encontrar uma singularidade particular, que remete diretamente à complexa questão da maternidade.

Nos relatos, a não-maternidade é vista de várias maneiras e tem várias justificativas, desde a impossibilidade orgânica 
(infertilidade), até o outro extremo, de mulheres que optaram deliberadamente pela não-maternidade. Essas últimas, chamadas pela autora de "transformadoras" ou "manifestantes precoces", constituem uma categoria minoritária de mulheres que rejeitam precocemente o papel materno, escolhendo uma vida, na qual, não há especificamente a necessidade de ter filhos. Em todos os relatos, perdura a emoção de cada entrevistada, de forma que a não-maternidade assume diversos significados, dependendo da perspectiva e do momento em que o tema foi objeto de reflexão pessoal.

Desse modo, o livro de Luci Mansur consiste no resultado de uma pesquisa recente sobre um fenômeno freqüente: a não-maternidade, principalmente na primeira década do século XXI mas, sem a suficiente investigação nos meios acadêmicos. Trata-se de uma leitura envolvente e emocionante pelos relatos das mulheres alvo da pesquisa. A autora, em seu diálogo relata a evolução social da mulher, ao mesmo tempo em que remete à realidade atual, a autora demonstra como o tema da não-maternidade se torna a cada momento histórico, percebido e tratado pela sociedade de forma diferente. Assim sendo, o livro pode ser considerado como um porta-voz da pluralidade e singularidade da experiência de mulheres em geral e de mulheres sem filhos em particular. O cuidado na construção e apresentação dos depoimentos e a complementar sensibilidade e inteligência das linhas de interpretação da autora, abrem o caminho para uma abordagem crítica da estigmatização, suscita pelas idéias de desvio e patologia e das visões estereotipadas que recaem sobre as mulheres sem filhos. É uma obra em que mais do que conclusões sobre o tema, Luci Mansur e as mulheres por ela entrevistadas, oferecem ao leitor, de forma generosa, uma oportunidade de rever sentimentos e idéias sobre a maternidade e a não-maternidade.

\section{Referência}

Mansur, L. H. B. (2003). Sem filhos: a mulher singular no plural. São Paulo: Casa do Psicólogo.

Recebido em 02.05.2005

Primeira decisão editorial em 13.02.2006

Versão final em 05.07.2006

Aceito em 09.11.2006 